\title{
PENGEMBANGAN MEDIA QUIET BOOK PADA PEMBELAJARAN TEMATIK DIKELAS IV SEKOLAH DASAR
}

\author{
Elas Sulastri M. Taufik, Zerri Rahman Hakim \\ Universitas Sultan Angeng Tirtayasa, Jl. Ciwaru Raya No. 2, Cipare, Kec. Serang, \\ Kota Serang, Banteng. Telp. (0254) 280330 \\ elassulastri0779@gmail.com, taufikmalalak@gmail.com, zerrirahmanhakim@gmail.com
}

\begin{abstract}
Abstrak; Penelitian ini berawal dari kurangnya keantusiasan siswa dalam proses pembelajaran siswa merasa cepat bosan sehingga siswa meminta bermain pada saat pembelajaran berlangsung sedangkan materi yang belum tersampaikan masih banyak. Penelitian ini bertujuan untuk mengatahui bagaiman kelayakan media Quiet Book sebagai media pada pembelajaran tematik dikelas IV B dan untuk mengetahui bagaimana respon siswa setelah menggunakan media pemebelajaran Quiet Book pada pembelajaran tematik dikelas IV B. Penelitian ini dilakukan di SD Negeri Karundang 2 dengan subjek penelitian di kelas IV B dengan 20 siswa pada uji angket respon siswa. Hasil uji validasi oleh para ahli terhadap kualitas media Quiet Book yang dikembangkan termasuk dalam kriteria sangat layak dengan presentase sebesar $85,4 \%$. Hasil uji angket respon siswa terhadap media Quiet Book mendapatkan kriteria sangat setuju dengan persentase sebesar 95\%. Berdasarkan hasil penelitian dapat disimpulkan bahwa media Quiet Book pada pembelajaran tematik dapat dikatakan sangat layak digunakan dalam pembelajaran tematik.
\end{abstract}

Kata Kunci: Media Quiet Book, Pembelajaran tematik.

\section{Abstract:}

This research starts from the lack of enthusiasm of students in the learning process students feel bored quickly so students ask to play while learning takes place while the material that has not been delivered is still a lot. This study aims to find out how the feasibility of Quiet Book media as a media in thematic learning in class IV B and to find out how students respond after using Quiet Book learning media in thematic learning in class $I V$ B. This research was conducted at Karundang 2 Elementary School with research subjects in class IV B with 20 students on the student response questionnaire test. The results of the validation test by the experts on the quality of the developed Quiet Book media are included in the very feasible criteria with a percentage of $85.4 \%$. The results of the questionnaire test students' responses to the media Quiet Book get criteria strongly agree with a percentage of 95\%. Based on the results of the study it can be concluded that the Quiet Book media on thematic learning can be said to be very feasible to use in thematic learning.

Keywords: Quiet Book Media, Thematic Learning. 


\section{PENDAHULUAN}

Pendidikan memiliki peranan yang penting dalam meningkatkan kualitas sumber daya manusia. Dalam prosesnya pendidikan terus mendorong sumber daya manusia untuk terus berinovasi menciptakan penemuan penemuan baru serta terus melakukan pembaharuan pengalaman agar sumber daya manusia dapat terus bersaing pada era globalisasi. Tidak hanya untuk meningkatkan kualitas SDM dalam bidang pengetahuan atau dalam bidang kemampuan tetapi juga berperan penting dalam meningkatkan nilai-nilai moral dan membentuk sumber daya manusia yang memiliki harkat serta martabat yang baik sebagai manusia yang beragama.

Begitu banyak karakter-karakter yang diharuskan ditanamkan pada siswa seperti karakter religius, perduli sosial, mandiri, percaya diri, disiplin, kerja keras, demokrasi, rasa ingin tahu, kreatif dan lain sebagainya. Pada jenjang pendidikan sekolah dasar guru dapat menanamkan karakter melalui proses pembelajaran dikelas baik dalam pembelajaran pada Kurikulum Tingkat Satuan Pendidikan (KTSP) mauapun pada pembelajaran tematik.

Saat ini Indonesia telah menerapkan pembelajaran tematik. Pembelajaran tematik iyalah pembelajaran terpadu yang memakai tema untuk mengaitkan atau menggabungkan mata pelajaran-mata pelajaran sehingga mampu mentransfer pengalaman berarti bagi siswa. Tema merupakan gagasan pokok yang menjadi inti pembicaraan. Meskipun pada pembelajaran tematik menggunakan tema namun masih terdapat mata pelajaran meskipun tidak dijelaskan secara jelas seperti yang terdapat dalam buku guru yang masih terdapat mata pelajaran dan terdapat kompetensi dasar dan setiap kompetensi dasar tersebut memiliki tujuan, meskipun pada buku siswa tidak dicantumkan. Kompetensi dasar yang diambil pada penelitian ini adalah kompetensi dari mata pelajaran IPS. Begitu banyaknya aspek-aspek ilmu yang terkandung dalam pendidikan IPS yang harus disampaikan kepada siswa, hampir semua aspek ilmu terkandung dalam pendidikan IPS terutama ilmu sosial yang senantiasa berkaitan erat dengan kehidupan sehari-hari yang dikerjakan oleh manusia.

Namun sampai saat ini fokus pembelajaran IPS yang diajarkan oleh guru 
dikelas masih bersifat text book, proses pembelajaran pada mata pelajaran IPS bersifat Teacher center, bahkan tidak hanya itu tidak sedikit guru yang tidak memakai media dalam proses pembelajaran dikelas, sekalipun menggunakan media biasanya media tersebut hanya berupa media gambar, kemudian materi yang terdapat dalam buku paket siswa cenderung banyak bacaan dan monoton sehingga membuat siswa malas membaca buku hal ini pun membuat siswa tidak aktif dikelas. Permasalahan tersebut sesaui dengan yang dikemukakan oleh M. Kaulan Karima (2009:45) mengemukakan bahwa masalah pembelajaran IPS yang terjadi saat ini dikarenakan dari pengaruh kebudayaan pada masa lampau terhadap mata pelajaran IPS, yang dianggap IPS sedikit kurang menarik, pendekatan indoktrinatif, second class, dianggap sepele, membosankan, dan bermacam-macam kesan negative lainnya telah menyebabkan mata pelajaran tersebut dilemma, belum lagi dengan fakta dilapangan yang menunjukan IPS masih dalam posisi pembelajaran konvensional, dll, hal inipun sesuai dengan pendapat Sitti Jauhar (2018:59) mengemukakan bahwa pembelajaran IPS dianggap sangat menjenuhkan baginya, guru hanya menjelaskan dengan trategi ceramah saja. Ini menunjukan bahwa dorongan siswa untuk belajar sangat rendah.

Sudah menjadi sebuah tanggung jawab dan kewajiban seorang guru untuk terus berusaha dan berinovasi mencari solusi dari permasalahan-permasalahan pembelajaran tersebut. Solusi untuk permasalahan pembelajaran IPS tersebut perlu adanya pengem bangan media, salah satunya yaitu mengembangkan media gambar menjadi media yang dapat dipadukan dengan keterangan materi dan dapat menjadi sebuat permainan yang menyenangkan serta dapat dibongkar pasang tentunya disesuikan dengan karakteristik siswa yaitu mengembangkan media gambar menjadi media Quiet Book yang dapat digunakan pada pembelajaran tematik khususnya pada pembelajaran IPS.

Keunggulan dari media Quiet Book pada penelitian ini dalam media Quiet Book terdapat latihan soal, bentuknya lebih besar dari Quiet Book pada umunya, terdapat simbol- simbol apresiasi misalnya berupa bintang, terdapat kantung materi, skor atau kata ucapan selamat kepada siswa yang berhasil menyelesaikan atau berhasil memasangkan komponen-kompenon yang terdapat dalam Quiet 
Book yang sesaui dengan perintah yang terdapat pada Quiet Book.

Dengan menggunakan media Quiet Book ini peneliti berharap agar siswa Sekolah Dasar tertarik untuk membaca materi IPS dan terdorong rasa ingin tahunya terhadap ilmu pengetahuan baik pengetahuan umum maupun ilmu pengetahuan sosial yang belum siswa ketahui sebelumnya karena siswa akan lebih bersemangat membaca materi yang terdapat dalam media jika media tersebut terlihat menarik terlebih jika media tersebut dapat dibongkar pasang sehingga siswa tersebut dapat bermain sambil belajar dengan begitu siswa dapat bermain sambil belajar dengan menyenangkan dan tidak membosankan.

\section{ACUAN TEORI}

Menurut Wulannasi dalam Samik Nuroh (2018: 19) Busy Book/ Quiet Book adalah media tiga dimensi jenis model/tiruan berupa buku kain bermatrian flanel yang terdiri dari halam-halaman yang berisi bermacam-macam kegiatan anak-anak seperti menghitung, mengenal warna, mengikat tali, mengenal satwa, dll yang bersifat educatif.

Menurut Mei Fita Sari Utari ( 2018: 377) mengemukakan bahwa media Quiet Book ini dikemas bseperti bentuk buku yang terbuat dari kain flanel di dalam Media Quiet Book siswa dapat berinteraksi langsung yaitu dengan bermain belajar sesuai dengan materi yang disajikan dalam Quiet Book seperti mencocokan gambar dengan tulisan dan lain sebagainya. Media quiet book merangsang keingintahuan peserta didik, meningkatkan psikomotorik peserta didik serta minat belajar peserta didik karena Quiet Book dirancang semenarik mungkin sesuai dengan usia dan perkembangan anak.

Menurut Gaity dalam Della Ulfa Amaris (2018:9) mengemukakan bahwa Bussy Book berisikan tentang aktivitas sehari-hari. Selain membuat anak sibuk dengan aktivitas yang positif, juga pengenalan pelajaran mandiri sejak dini. Didalam busy book, anak menemukan permainan-permainan unik yang menyenangkan yang mengasah kognitifnya. Menurut Sa'ud akbar (2015:4) beliau mengemukakann bahwa pembelajaran tematik adalah pembelajaran terpadu yang menggunakan tema untuk mengaitkan beberapa mata pelajaran sehingga dapat memberikan pengalaman bermakna bagi siswa. 


\section{METODE PENELITIAN}

Desain penelitian yang digunakan dalam penelitian ini iyalah model penelitian dan pengemban gan (reasearch \& development). Menurut Sugiyono (2013:407) mengatakan bahwa metode penelitian dan pengembangan adalah metode penelitian yang digunakan untuk menghasilkan produk tertentu, dan menguji keefektifan poduk tertentu..Dalam penelitian pengembangan ini, menghasilkan produk berupa media pembelajaran Quiet Book.

Beracuan pada metode penelitian dan pengembangan (R\&D) dalam Sugiono yang menyebutkan 10 langkah, peneliti mengambil 6 langkah dalam proses ini. Tidak hanya itu, dalam penelitian ini keterbatasan peneliti hanya bisa merealisasikan penelitian R\&D dalam skala kecil. Hal ini di karenakan dalam R\&D salah satunya peneliti hanya bisa merealisasikan dalam jumlah terbatas namun hal tersebut dirasa telah memenuhi pokok dari penelitian pengembangan. Adapun langkah-langkahnya adalah sebagai berikut.

\section{Potensi Masalah}

Potensi dan masalah yang di peroleh melalui wawancara yang dilakukan di SDN Karundang 2 pada ibu Khuriyah wali kelas 4 pada tanggal 25 September 2019. Dalam proses mengajarnya beliau sudah menggunakan media berupa media gambar, teks, teka-keti silang dan lain sebagainya. Meskipun telah menggunakan media gambar pada saat pembelajaran namun siswa masih kurang antusias, tidak hanya itu pada saat pembelajaran berlangsung banyak siswa yang mulai bosan dan minta untuk bermain, namun ibu Khuriyah tidak bisa terus mengikuti keinginan siswa untuk permainan di tengah waktu pelajaran karena masih banyak materi yang harus disampaikan.

Selain permasalahan tersebut beliau juga mengatakan bahwa pada saat beliau mengajak siswa untuk mengisi pertanyaan yang ada pada buku paket tematik sudah menjadi suatu kebiasaan jika siswa bertanya jawaban dari pertanyaan yang terdapat pada buku paket tersebut Oleh karena itu peneliti Ingin mengembangkan media pembelajaran Quiet Book karena media tersebut dapat dibongkar pasang dan terbuat dari kain flanel yang didalam media tersebut terdapat aktivitas atau kegiatan pembelajaran yang menarik seperti menjodohkan, mencocokkan dan lain 
lain sehingga dalam proses pembelajaran guru dapat dengan mudah melibatkan siswa secara aktif dalam belajar.

\section{Pengumpulan Informasi}

Pengumpulan data diselenggarakan dengan cara melaksanakan analisis kebutuhan melalaui guru wali kelas 4 di SDN Karundang 2 tentang penggunaan media pembelajaran dan kendala selama proses pembelajaran dikelas. Selain itu peneliti juga mengumpulkan data melalui angket uji kelayakan produk kepada para ahli terkait seperti ahli bahasa, ahli media, ahli materi dan angket respon siswa yang tujuannya untuk mengetahui respon siswa terhadap pengembangan media Quiet Book dikelas 4 SDN Karundang 2. Tidak hanya itu peneliti juga melaksanakan dokumentasi pada saat melakukan penelitian yang berupa foto untuk melihat kondisi lapangan saat penelitian berlangsung

\section{Desain Produk}

Pengembangan produk yang akan dibuat berupa media pembelajaran Quiet Book yang didesain menggunakan kain flanel dijahit dan dipadukan dengan beberapa bagian yang dicetak menggunakan kertas karton kemudian diperkuat dengan proses laminating. Tahapan ini merupakan tahapan perencanaan media pembelajaran yang telah dibuat dari tahapan pengumpulan data sebelumnya. Tahapan ini juga merancang storyboard dan instrument yang akan digunakan. Pengembangan produk ini masih belum terbukti kelayakannya, maka perlu adanya uji ahli terlebih dahulu.

\section{Validasi Produk}

Sebelum di uji cobakan produk yang telah dikembangkan harus melewati tahapan validitas (uji ahli) terlebih dahulu. Tujuannya agar mengetahui apakah media tersebut telah memenuhi syarat atau belum. Uji ahli validitas media ini dilaksanakan dalam 3 kategori, yaitu uji media, uji materi, dan uji bahasa. Ahli ahli tersebut merupakan dosen Universitas Sultan Ageng Tirtayasa dan dosen dari Universitas Islam Negeri Sultan Maulana Hasanudin Banten.

\section{Perbaikan Desain}

Setelah desain produk dikonfirmasi melalui bertukar pendapat dengan pakar dan para ahli lainnya, maka akan dapat diketahui kelemahannya dari. Kelemahan 
tersebut selanjutnya di uji coba untuk diminimalisir dengan cara memperbaiki desain. Yang bertugas untuk memperbaiki desain iyalah peneliti yang akan menghasilakan produk tesebut.

\section{Uji Coba Produk}

Media pembelajaran Quiet Book yang telah di validasi oleh tim ahli selanjutnya di tindak lanjut dengan diselenggarakannya uji coba terbatas. Uji coba terbatas ini diselenggarakan di SDN Karundang 2 populasi pada uji coba terbatas ini iyalah peserta didik kelas IV B di SDN Karundang 2 dan sampel yang digunakan pada penelitian ini iyalah sebanyak 20 orang peserta didik. Teknik pengambilan sampel ini dipakai teknik purposive yaitu teknik pengambilan sampel dengan pertimbangan tertentu sesuai dengan tujuan pengambilan sampel pada penelitian. Pada uji coba terbatas ini siswa diajak oleh guru untuk mengisi atau menjawab pertanyaan atau pernyataan yang terdapat dalam lembar angket untuk mengetahui respon penailaian peserta didik terhadap media pembelajaran yang digunakan tersebut.

Lokasi penelitian ini yaitu SD Negeri Karundang 2 Serang, penelitian ini dilakukan pada tanggal 14 maret 2020.

Teknik pengumpulan data yang dilakukan pada penelitin ini adalah wawancara, Angket, dan dokumntasi. Wawancara merupakan teknik atau cara pengumpulan data melalui mengajukan pertanyaan kepada responden dan mencatat atau merekam jawaban-jawaban responden. Wawancara bisa diselenggaran secara langsung ataupun tidak langsung dengan sumber data atau responden. Angket meruapakan teknik atau cara pengumpulan data dengan memberikan atau mengirimkan daftar pertanyaan untuk diisi oleh responden, Selanjutnya dokumentasi adalah cara pengumpulan data yang tidak langsung ditunjukan pada subjek penelitian, tetapi melalui dokumen.

Instrumen pengumpulan data yang digunakan pada penelitian ini adalah: 1). Pedoman wawancara tidak terstruktur yang dipakai untuk melakukan wawancara pengembangan media pembelajaran di Sekolah dasar, 2) Angket validitas media atau lembar penilaian oleh uji ahli media untuk mengukur kelayakan media Quiet Book, 3) Angket penilaian media oleh ahli materi ditujuakn untuk mengetahi dan 
mengukur kelayakan media pembelajaran dari segi muatan materi, 4) Angket penilaian media oleh ahli bahasa ditujukan untuk mengetahui dan mengukur kelayakan media dari segi muatan penggunaan bahasa, 5) Angket respon peserta didik yang dimaksudkan untuk mengetahui respon peserta didik.

Teknik Analisis hasil Uji Instrumen pada penelitian ini dengan cara uji validasi desain produk dan penyebaran angket respon siswa dengan kriteria interprestasi sebagai berikut:

Tabel 1: kriteria Uji Kelayakan Media Quiet Book angket respon siswa

\begin{tabular}{cl}
\hline Presentasi Pencapaian & Interprestasi \\
\hline $80 \%-100 \%$ & Sangat Layak \\
\hline $61 \%-80 \%$ & Layak \\
\hline $41 \%-60 \%$ & Cukup Layak \\
\hline $21 \%-40 \%$ & Kurang Layak \\
\hline $0 \%-20 \%$ & Tidak Layak \\
\hline
\end{tabular}

\section{HASIL DAN PEMBAHASAN}

Penelitian dan pengembangan ini mempunyai tujuan untuk menghasilkan sebuah media pembelajaran Quiet Book pada materi pemanfaatan sumber daya alam di kelas IV sekolah dasar. Penelitian ini dilakukan berdasarkan prosedur pengembangan yang dikembangkan oleh Sugiyono. Tahapan pada penelitian ini antara lain, (1) Potensi dan masalah (3) Pengumpulan informasi (3) Desain produk (4) Validasi desain (5) Revisi desain (6) Uji coba produk (terbatas).

\section{Potensi masalah}

Tahap ini diawali dengan melakukan wawancara tidak terstruktur pada wawancara tersebut didapatkan informasi bahwa siswa kurang termotivasi dalam belajar, membaca buku dan merasa bosan dalam mengisi pertanyaan yang terdapat dalam buku paket tematik sehingga materi kurang tersampaikan dengan baik kepada siswa

\section{Pengumpulan data}

Pengumpulan data diselenggarakan dengan melakukan analisis kebutuhan 
melalaui guru wali kelas IV B di SDN Karundang 2 tentang penggunaan media pembelajaran dan kendala selama proses pembelajaran dikelas. Peneliti pun mengumpulkan data melalui angket uji kelayakan produk kepada para ahli terkait seperti ahli bahasa, ahli media, ahli materi dan angket respon siswa yang tujuannya untuk mengetahui respon siswa terhadap pengembangan media Quiet Book dikelas IV B SDN Karundang 2.

Selain itu peneliti juga mengambil dokumentasi pada saat penelitian berlangsung yaitu berupa gambar atau foto untuk melihat keadaan lapangan saat penelitian dilaksanakan.

\section{Desain Produk}

Tahap awal dari pembuatan media pembelajaran Quiet Book ini dilakukan dengan membuat Storyboard. Tahap selanjutnya yaitu pembuatan produk media pembelajaran Quiet Book pada pembelajaran tematik dikelas IV.

Langkah-langkah yang dilakukan yaitu pertama membuat kartu materi dan kartu-kartu pertanyaan, materi yang diambil diselaraskan dengan kompetensi dasar yang terdapat pada buku tema guru dan siswa, bagian materi terdapat contoh gambar yang diambil dari internet yang telah disesuaikan dengan materi dan kehidupan sehari-hari serta disesuaikan dengan lingkungan siswa, kemudia Gambar yang telah dipilih diedit dengan mengunakan PowerPoint, gambar di desain menjadi kartu dan diberikan keterangan.

Setelah materi, gambar, pertanyaan-pertanyaan diedit dengan pengaturan background dan didesain menjadi kartu yang menarik pada aplikasi PowerPoint langkah selanjutnya yaitu pencetakan kartu.

Langkah selanjutnya adalah membuat Media Quiet Book, bahan dasar dari Quiet Book pada penelitian ini adalah kain flanel. Pembuatan Quiet Book ini dibentuk seperti buku yang pada setiap lembarnya terdapat kantung-kantung, mulai dari kantong materi sampai kantung pertanyaan, kantung-kantung ini diisi dengan kartu materi dan kartu pertanyaan.

\section{Validasi Desain}

Media Quiet Book dinyatakan layak apabila hasil penilaian dari validator yaitu $61 \%-80 \%$. Adapun hasil hasil uji validasi terhadap pengembangan media Quiet 
Book pada pembelajaran tematik yang telah dinilai oleh validator disajikan sebagai berikut:

Validator ahli media memvalidasi aspek kelayakan media dan aspek kelayakan komunikasi visual. Rata-rata hasil penilaian validator terhadap kelayakan media Quiet Book pada pembelajaran sebagai berikut.

Tabel 2: Data Penilaian Validasi Ahli Media

\begin{tabular}{ccc}
\hline No & Kriteria & Penilaian ahli \\
\hline 1 & Aspek kelayakan media & 36 \\
\hline 2 & Aspek Komunikasi visual & 20 \\
\hline & Jumlah & 56 \\
\hline & Presentase Nilai \% & $80 \%$ \\
\hline & Interprestasi & Layak \\
\hline
\end{tabular}

Menurut hasil validasi media tersebut bisa diambil kesimpulan bahwa media pembelajaran Quiet Book pada pembelajaran tematik yang dikembangkan mendaptkan interprestasi layak.

Validator ahli materi memvalidasi aspek kelayakan isi materi, aspek kelayakan penyajian, dan aspek penialian kontekstuall. Rata-rata hasil penilaian validator terhadap kelayakan materi pada media Quiet Book pada pembelajaran tematik sebagai berikut.

Tabel 3: Data Penilaian Validasi Ahli Materi

\begin{tabular}{ccc}
\hline No & Kriteria & Penilaian ahli \\
\hline 1 & Aspek kelayakan isi materi & 14 \\
\hline 2 & Aspek kelayakan penyajian & 19 \\
\hline 3 & Aspek kelayakan kontektual & 20 \\
\hline & Jumlah & 53 \\
\hline & Presentase Nilai \% & $88,3 \%$ \\
\hline & Interprestasi & Sangat Layak \\
\hline
\end{tabular}

Berdasarkan hasil validasi ahli materi tersebut bisa diambil kesimpulan bahwa materi yang terdapatpada media pembelajaran Quiet Book pada pembelajaran tematik yang dikembangkan mendaptkan interprestasi sangat layak.

Validator ahli bahasa memvalidasi aspek kelayakan bahasa. Rata-rata hasil penilaian validator terhadap kelayakan bahasa pada media Quiet Book pada 
pembelajaran tematik sebagai berikut.

Tabel 4: Data Penilaian Validasi Ahli Bahasa

\begin{tabular}{ccc}
\hline No & Kriteria & Penilaian ahli \\
\hline 1 & Kelayakan bahasa & 44 \\
\hline & Jumlah & 44 \\
\hline & Presentase nilai\% & $88 \%$ \\
\hline & Interprestasi & Sangat Layak \\
\hline
\end{tabular}

Berdasarkan hasil validasi ahli bahasa tersebut bisa diambil kesimpulan bahwa bahasa yang terdapatpada media pembelajaran Quiet Book pada pembelajaran tematik yang dikembangkan mendaptkan interprestasi sangat layak.

\section{Revisi Produk}

Pada tahap ini, bahan ajar yang telah divalidasi, langkah selanjutnya diperbaiki sesuai dengan masukan dari para ahli pada saat validasi dilakukan. Selanjutnya dilakukan perbaikan terhadap Media Quiet Book pada pembelajaran tematik. Melalui hasil validasi oleh ahli media, diketahui bahwa media pembelajaran Quiet Book pada pembelajaran tematik masih memerlukan revisi pada bagian-bagian tertentu, pada hasil validasi ahli materi diketahui bahwa materi yang terdapatpada media pembelajaran Quiet Book pada pembelajaran tematik masih memerlukan penambahan beberapa bagian pada bagian penyajian materi seperti belum adanya kolom bertanya dan belum terlampirnya daftar pustaka agar tidak menimbulkan miskonsepsi, selanjutnya melalui hasil validasi oleh ahli bahasa, diketahui bahwa penggunaan tata bahasa dan penggunaan aturan penulisan masih yang terdapat pada media pembelajaran Quiet Book pada pembelajaran tematik masih memerlukan perbaikan penulisan agar tidak menimbulkan miskonsepsi menurut saran atau komentar yang telah diberikan oleh ahli bahasa.

\section{Uji Coba Produk}

Uji coba dilakukan dengan cara penggunaan media Quiet Book dalam pembelajaran tematik di kelas. Untuk mengetahui respon dari siswa, Media Pembelajaran Quiet Book pada pembelajaran tematik ini dilakukan uji coba 
terbatas kepada siswa kelas IV B SDN Karundang 2 dengan jumlah keseluruhan siswa sebanyak 31 siswa namun yang diambil sebagai sampel pada penelitian ini hanya 20 siswa sebagai responden. Berdasarkan hasil responden siswa terhadap media pembelajaran Quiet Book pada pembelajaran tematik diperoleh presentase nilai akhir sebesar 95\% termasuk kedalam kategori "sangat baik".

Pengembangan media pembelajaran ini diharapkan dapat membangkitkan motivasi serta keantusiasan siswa dalam belajar dengan atau tanpa adanya guru.

Setelah dilakukan tahapan pengembangan desain produk, lalu dilakukannya validasi desain produk. Berdasarkan hasil uji validasi yang telah dilakukan oleh beberapa validator, baik ahli media, ahli materi, dan ahli bahasa. Peneliti mendapatkan perolehan skor dari setiap-masing-masing validator sebagai berikut:

Tabel 5: Rata-rata Validasi Ahli

\begin{tabular}{ccc}
\hline Hasil Validasi & Presentase\% & Kategori \\
\hline Ahli Media & 80 & Layak \\
\hline Ahli Materi & 88,3 & Sangat Layak \\
\hline Ahli Bahasa & 88 & Sangat Layak \\
\hline Rata-Rata & 85,4 & Sangat Layak \\
\hline
\end{tabular}

Berdasarkan tabel diatas menunjukan tingkat hasil penilaian berdasarkan rata-rata presentase dari penilaian uji validasi dari setiap ahli (Ahli media, materi, dan bahasa). Hasil tabel diatas memperlihatkan bahwa rata-rata skor tertinggi didapatkan dari hasil validasi ahli materi, dengan persetase skor sebesar $88,3 \%$. Hal tersebut menunjukan bahwa pengembangan media pembelajaran Quiet Book pada pembelajaran tematik ini telah memenuhi salah satu kriteria dari indikator keberhasil yang telah ditetapkan sebelumnya, yaitu penilaian dari para ahli.

Skor tersebut didapatkan karena penyajian materi yang terdapat pada media Quiet Book dapat mendorong menemukan informasi serta membantu siswa dalam mengaitkan materi yang diajarkan dengan kehidupan sehari-hari siswa. Hal ini sesuai dengan yang dikemukakan oleh Nurul Isnaeni, (2018:31) bahwa bahwa manfaat media Quiet Book dapat mendorong kreatifitas anak untuk terus meningkat, selain itu, manfaat Quiet Book membuat anak mudah belajar dan memahami materi yang diajarkan.

Kemudian hasil validasi terendah didapatkan dari validasi ahli media sebesar 
$80 \%$. Hal tersebut menunjukan bahwa pengembangan media pembelajaran Quiet Book pada pembelajaran tematik telah memenuhi salah satu kriteria dari indikator keberhasilan yang telah ditetapkan sebelumnya, yaitu penilaian dari para ahli. Dimana hasil penilaian dari ahli media ini sudah masuk kedalam kategori "layak".

Jika diperhatikan dari tabel rata-rata skor yang tertera diatas, maka bisa din nyatakan bahwa media pembelajaran Quiet Book pada pembelajaran tematik memperoleh nilai uji kelayakan media yang cukup tinggi dengan perolehan angka rata-rata sebesar $85,4 \%$ melalui uji validasi ahli, sehingga mendapatkan kategori "sangat layak".

Hal ini dikarenakan media Quiet Book dapat berfungsi dengan baik pada proses pembelajaran hal ini sesaui dengan teori fungsi media menurut Arsyad, (2014:20) yang mengatakan bahwa media mampu memotivasi, mampu memberikan pesan isi dan bentuk penyajian materi, selain itu media berguna untuk tujuan instruksi di mana pesan yang terdapat dalam media itu harus melibatkan siswa baik yang terdapat dalam benak atau mental maupun dalam bentuk kegiatan yang nyata sehingga pembelajaran dapat terjadi dengan baik.

Kemudian untuk respon siswa, mendapatkan hasil rata-rata skor persentase sebesar 95\% dengan kriteria "sangat baik" dari respon siswa. Melalui skor persentase yang diperoleh, dapat diketahui bahwa media pembelajaran Quiet Book pada pembelajaran tematik ini telah memenuhi indikator keberhasilan yang telah ditetapkan sebelumnya sehingga mendapat kriteria "sangat baik". Hal ini dikarenakan media yang dikembangkan memiliki kemenarikan, dan mampu membangkitkan semangat siswa untuk membaca dan menjawab pertanyaan dengan menyenangkan bagi siswa kelas IV B SDN Karundang 2.

Namun nilai tersebut belumlah sempurna dikarenakan adanya perbedaan karaketeristik pada setiap siswa. Menurut Masganti (2012:5) mengemukakan bahwa setiap orang mempunyai perkembangan yang berbeda-beda termasuk pada anak kembar. meskipun bentuk perkembangan sama pada setiap anak, setiap anak bisa mengikuti pola yang dapat diramalkan melaui cara serta kecepatan sendiri. Sebagian anak berkembang dengan mudah, bertahap-tahap. Perbedaan ini dikarenakan semua orang mempunyai unsur biologis dan genetic yang berbeda. 
Misalnya pada perbedaan kecerdasan.

Dari hasil penelitian bisa dikatakan bahwa media pembelajaran Quiet Book dapat digunakan sebagai media dalam pembelajaran khusus pada materi IPS yaitu materi pemanfaatan sumber daya alam di kelas

\section{SIMPULAN DAN SARAN}

Menurut hasil penelitian dan pengembangan Media Pembelajaran Quiet Book pada Pembelajaran Tematik untuk kelas IV B SDN Karundang 2 semester 2, maka bisa kesimpulan sebagai berikut:

1. Kelayakan media pembelajaran Quiet Book pada pembelajaran tematik diperoleh melalui hasil penilaian ahli desain, ahli materi, dan ahli bahasa. Hasil penilaian dari ahli media/desain, memperoleh persentase nilai akhir $80 \%$ yang tergolong dalam kriteria “ layak". Hasil penilaian dari ahli materi, persentase nilai akhir $88,3 \%$ yang masuk pada kriteria "sangat layak". Hasil penilaian dari ahli bahasa, memperoleh persentase nilai akhir $88 \%$ yang masuk pada kriteria "sangat layak". Jika dihitung pencapaian hasil penilaian validasi ahli, maka bisa dikatakan bahwa media pembelajaran Quiet Book pada pembelajaran tematik ini memperoleh nilai uji kelayakan yang tinggi dengan mendapatkan angka rata-rata sebesar 85,4\% dengan melakukan uji validasi ahli, sehingga mendapatkan kategori "sangat layak". Hal ini menunjukan bahwa media pembelajaran Quiet Book pada pembelajaran tematik dapat digunakan pada pembelajaran tematik disekolah dasar kelas IV.

2. Respon siswa terhadap media pembelajaran Quiet Book yang dikembangkan pada tahapm uji coba produk yang melibatkan 20 siswa memdapatkan rata-rata skor presentase sebesar 95\% dengan kriteria "Sangat baik". hal ini menunjukan bahwa media pembelajaran Quiet Book pada pembelajaran tematik dapat digunakan pada pembelajaran tematik disekolah dasar kelas IV. 


\section{DAFTAR RUJUKAN}

Arsyad, Azhar. 2014. Media Pembelajaran. Jakarta: PT Raja Grafindo Persada. Isnaeni.Nurul. 2018. Kemampuan Kemampuan Kognitif Melalui Permainan Quiet Book Pada Kelompok A RA Masyithoh Kalibening Salatiga. Skiprsi Sarjana. Salatiga. Instritut Agama Islam Negeri.

Jauhar, Sitti. 2018. Pengembangan Bahan Ajar IPS Berbasis Pendekatan SAINS Teknologi Mayarakat (STM) Untuk Meningkatkan Kreativitas Siswa Di Sekolah Dasar. Vol, 2. No, 2. http://doi.org/10.26858/jkp.v2i2.6946.27. 27 April 2020.

Masganti. 2012. Perkembangan Peserta Didik. PERDANA PUBLISING. Medan. Muhammad Kaulan Karim, 2009. Masalah Pembelajaran IPS dan Strategi Jitu Pemecahannya. Vol,11.No,1. http://repository.unisu.ac.id/id/eprint/5718. 27 April 2020

Sugiyono. 2014. Metode Penelitian Kuantitatif kualitatif dan RnD. Bandung. ALVABETA, cv.

Sugiyono. 2013. Metode Penelitian Pendidikan. Bandung. ALVABETA. Cv.

Samik Nuroh Ramadhan. 2018. Media Quiet Book dalam Meningkatkan Keterampilan Memakai Baju Berkancing Bagi Anak Tunagrahita. Vol. 4. No. 1.

Mei Fita Asri Utari. 2018. Pengembangan Media Quiet Book untuk Pembelajaran Tematik Keluargaku Di Sekolah Dasar Kelas 1. Vol 3. No. 4. http://dx.doi.org/10.28926/briliant.v3i3.196. 24 juni 2020.

Della Ulfa Amaris. 2018. Pengaruh Media Busy Book Terhadap Kemampuan Berhitung Anak Usia Dini Di Taman Kanak-kanak Fadhilah Amal 3 Padang. Vol.4. No. 2. http://repository.unp.ac.id/id/eprint/21233. 24 Juni 2020 .

Akbar Sa'ud. 2015. Pembelajaran Tematik. Malang. IKIP MALANG 